\title{
JNVESTJGAACJÓN
}

\section{A simple model of the diffusion phenomena taking place during the debittering process of green table olives}

\author{
By Mariela B. Maldonado, ${ }^{\star 1,2}$ Carlos A. Zuritz, ${ }^{1,4}$ Rodolfo G. Wuilloud, ${ }^{1,3}$ Carlos R. Bageta, ${ }^{4}$ \\ Jorge Terreni ${ }^{4}$ and María José Sánchez ${ }^{2}$
}

\author{
${ }^{1}$ Research Scientists of the Consejo Nacional de Investigaciones Científicas \\ y Técnicas (CONICET), Argentina \\ ${ }^{2}$ Instituto Nacional de Tecnología Agropecuaria EEA-Mendoza (INTA), Argentina. \\ ${ }^{3}$ Instituto de Ciencias Básicas, Universidad Nacional de Cuyo, Centro Universitario, Parque Gral. San \\ Martín, Mendoza, Argentina \\ ${ }^{4}$ Facultad de Ciencias Agrarias, Universidad Nacional de Cuyo. Alte. Brown 500, (5505) Chacras de \\ Coria, Mendoza, Argentina \\ ( ${ }^{*}$ Corresponding author: mmaldonado@ mendoza.inta.gov.ar, marielabeatriz1972@yahoo.com.ar)
}

\section{RESUMEN}

Un modelo simple del fenómeno de difusión que tiene lugar durante el proceso de desamarizado de aceitunas verdes de mesa.

Se ha cuantificado el cambio en la concentración de sodio y calcio en la pulpa y en la lejía durante el tratamiento alcalino de aceitunas. La concentración promedio de sodio en la pulpa aumentó de 0,0045 a 0,395 meq $\mathrm{Na} / \mathrm{g}$ mientras que la de calcio creció de 0,018 a 0,0252 meq Ca/g. La textura de las aceitunas disminuyó casi linealmente de $375 \mathrm{gf}$ a $235 \mathrm{gf}$ durante el tratamiento alcalino. Las aceitunas sufrieron una perdida de azúcares reductores del $25.9 \%$. Se ha propuesto una hipotética y simplificada descripción de la dinámica de los cambios de carga iónica y el desenrrollamiento de las pectinas durante el desamarizado de las aceitunas. También se calculó el coeficiente efectivo de difusión para sodio y calcio usando un modelo de difusión para una placa compuesta. Los coeficientes resultaron en el orden de $10^{-12} \mathrm{~m}^{2} / \mathrm{s}$ para la piel y $10^{-10} \mathrm{~m}^{2} / \mathrm{s}$ para pulpa. En ambos casos el coeficiente de difusión de $\mathrm{Na}$ fue mayor que el de $\mathrm{Ca}$.

PALABRAS CLAVE: Calcio - Carga iónica - Difusión Sodio - Tratamiento alcalino de aceitunas verdes.

\section{SUMMARY}

A simple model of the diffusion phenomena taking place during the debittering process of green table olives.

The change in the concentration of sodium and calcium ions in the olive flesh and in the lye during the debittering process was quantified. The average concentration of $\mathrm{Na}$ increased from 0.0045 to $0,395 \mathrm{meq} \mathrm{Na} / \mathrm{g}$ of olive flesh and the concentration of $\mathrm{Ca}$ increased from 0.018 to $0.0252 \mathrm{meq} \mathrm{Ca} / \mathrm{g}$ of olive flesh. The firmness of the olives decreased almost linearly from 375 gf to 235 gf during the alkali treatment. The olives also suffered a $25.9 \%$ loss in their initial content of reducing sugars. A hypothetical simplified description of the dynamic of ionic charge changes and unwinding of the pectinic structure during the debittering process of green olives has been proposed. In addition, the effective diffusion coefficients were calculated for sodium and calcium using a diffusion model for a composite flat plate and constant diffusion coefficients. The coefficients for both solutes were in the order of $10^{-12} \mathrm{~m}^{2} / \mathrm{s}$ for the skin and $10^{-10}$ $\mathrm{m}^{2} / \mathrm{s}$ for the flesh. In both cases, the diffusion coefficients of $\mathrm{Na}$ were larger than the diffusion coefficients of $\mathrm{Ca}$.

KEY-WORDS: Calcium - Diffusion - Debittering of green olives - lonic charge - Sodium.

\section{INTRODUCTION}

The diffusion of solutes in food products plays an important role in many food processes, such as drying, chemical peeling, etc., as well as in the processing of fermented green olives. Given that the progress of chemical reactions that take place within the food depends on the diffusion of the reactants, these phenomena affect the progress of the processes and also the quality of the final products.

The simultaneous and individual diffusion of citric and ascorbic acid have been studied in potato tissue, cut into spheres of various diameters for different immersion times and agitation conditions. In this work the researchers determined effective diffusion coefficients for the acids diffusing individually and used multi-component analysis to evaluate interaction coefficients for the mixture of the two acids (Lombardi and Zaritzky, 1997). The effect of sodium hydroxide on the structure of pimiento peppers during peeling was evaluated using electron microscopy. The authors remarked the importance of controlling the lye concentration and exposure time in order to avoid structural damage of the tissue (Floros et al., 1987).

The first step in the processing of fermented green olives is a lye treatment known as debittering. The lye treatment gives rise to complex chemical and physical changes in the olives, and its extent 
also affects the subsequent diffusion of salt and the progress of the lactic fermentation (Rodríguez de la Borbolla y Alcalá, Rejano, 1979., Sciancalepore, 1984). The main objectives of this operation are to eliminate the bitter taste conferred by the glycoside oleuropein and to increase the permeability of the fruit. The skin is a natural barrier to the penetration of $\mathrm{NaOH}$ and other solutes to the interior of the olives. Its permeation is a function of the treatment conditions such as lye concentration and temperature, along with olive variety and maturity (Barranco et al., 1987).

The effect of lye concentration (Maldonado et al., 2003) and temperature (Zuritz et al, 2003) on the diffusion of $\mathrm{NaOH}$ was studied during the debittering of olives of the Arauco variety. The diffusion of sodium chloride into green olives placed in brines of various concentrations has also been quantified (Drusas et al., 1988). In this work, the authors studied untreated olives and olives pretreated with lye at $1.8 \%(\mathrm{w} / \mathrm{v})$ for $6 \mathrm{~h}$ and calculated salt effective diffusion coefficients assuming a hollow sphere geometry and negligible external resistance to mass transfer. They measured the absorption of salt from changes in brine concentration.

Effective diffusion coefficients of sodium during the debittering of the green olive varieties Arauco and Aloreña have also been computed (Maldonado and Zuritz, 2003, 2004). The diffusion of sodium through olive skin during and after treatment with $\mathrm{NaOH}$ (Zuritz and Maldonado, 2004), as well as the diffusion phenomena considering variable diffusion coefficients (Maldonado and Zuritz, 2004) have been recently studied. In both cases an increase in the skin diffusion coefficient with treatment time was observed. The same authors studied the diffusion of glucose and sodium chloride in olives as affected by different lye concentrations and different concentrations of sodium chloride (Maldonado et al., 2008a, 2008b).

Texture, or fruit firmness, is significantly affected during the debittering and subsequent processing steps. The changes in texture and solubilization of cell wall polysaccharides during the processing of Spanish green olives have been extensively studied by different researchers (Jiménez et al., 1995, 1996, 1997, 1998; Coimbra et al., 1996). They observed a marked decrease in texture during lye treatment and washing and a noticeable increase after soaking the olives in brine. The lye treatment had the greatest effect on uronic acid-containing fractions, producing saponification of ester linkages yielding oxalate soluble polysaccharides. They indicate that electrostatic interactions and changes in the gel structure of pectic polysaccharides and the breakdown of linkages between pectic and hemicellulosic polysaccharides could be the most important factors in the loss of texture during lye treatment. The polymers with a low degree of esterification are mainly stabilized in the cell wall by ionic bonds with calcium, and therefore, an increase in their amount or ionic charge could result in a substantial recovery of the firmness lost during the lye treatment. The softening of the olive pulp was due to a partial degradation of the pectic polysaccharides. Cell-cell adhesion is also modulated by the presence of $\mathrm{Ca}^{+2}$; its removal or displacement by ions, such as $\mathrm{Na}^{+}$, can reduce tissue firmness.

Despite the amount of studies reported on cell wall and pulp physicochemical changes during the processing of green olives, the diffusion and distribution of calcium within the pulp has not yet been quantitatively addressed, particularly in comparison with the diffusion of sodium and other solutes.

The present work presents the results obtained in the quantification of the diffusion phenomena of sodium, calcium and other components in and out of the olives during the debittering process done at industrial scale. Also, a simplified description of the dynamic of charge changes of ions is proposed to explain and complement the results being reported.

\section{MATERIALS AND METHODS}

\subsection{Sampling}

Green olives of the variety "Arauco" were used in this study. They were harvested with a Maturity Index (M.I.) 2 (Fernández et al., 1991), corresponding to a green-yellow skin color, with few red spots. The M.I. scale ranges from 0 for olives with a skin color of intense green to 7 for olives with black skin and totally purple flesh. A sample of 100 olives, randomly selected from the total amount of olives chosen for processing, was measured giving the following average dimensions and standard deviations (s): weight $=5,593 \times 10^{-3} \mathrm{~kg}, \mathrm{~s}=0.915 \times 10^{-3} \mathrm{~kg}$; equatorial diameter $=20.50 \times 10^{-3} \mathrm{~m}, \mathrm{~s}=1.59 \times 10^{-3}$ $\mathrm{m}$; length $=31.38 \times 10^{-3} \mathrm{~m}, \mathrm{~s}=2.20 \times 10^{-3} \mathrm{~m}$. A skin thickness of $4.0 \times 10^{-5} \mathrm{~m}$ was obtained from a sample of 25 olives. The skin was removed with the help of a sharp thin blade, carefully eliminating any mesocarpic cells attached and avoiding cuts and breakage of the skin. The skin thickness was measured with a digital caliper Palmer Helios 0-150 mm - Germany (1:100 mm).

The olives were placed in two large rectangular containers made of concrete, each of them holding $2100 \mathrm{~kg}$ of olives and 1900 liters of lye. At each sampling time; lots of twenty (20) olives and 20 $\mathrm{ml}$ of lye from two (2) different levels (L1: $1 / 3$ and L2: $2 / 3$ from the surface) were removed from each container for analysis. Each olive was pierced at the equatorial axis, all the way to the pit, with a 5-mm diameter glass tube with a sharp edge, perpendicularly to the longitudinal axis. The flesh trapped in the glass tube was then separated from the olive by cutting at the pit level. Each cylindrical sample was subsequently cut into four disks of average thickness of $1.2 \mathrm{~mm}$ each (measured with a 1:50 mm caliper Palmer Helios - 0-150 mm - Germany), each constituting a distinct sample for both sodium and calcium determinations. 


\subsection{Analytical Methods}

Each disk-shaped sample was weighed in an OHAUS AP2105 (New Jersey, USA) Balance with a precision of $0.1 \mathrm{mg}$ and then placed in a porcelain dish with a lid. The samples were subsequently oven dried at $100 \pm 5^{\circ} \mathrm{C}$ for $24 \mathrm{~h}$ and then placed in a furnace at $550 \pm 25^{\circ} \mathrm{C}$ until white ashes were obtained.

The ashes were quantitatively recovered with 2 $\mathrm{ml}$ of a $1+1$ solution of $\mathrm{HCl}$ analytical grade purity (agp) Merck (sodium free) and $10 \mathrm{ml}$ of deionized water in a test tube.

The sodium content in the above solution was measured in a flame photometer Metrolab model 315 (Buenos Aires, Argentina) by direct injection, prior to calibration of the equipment with a standard solution of $\mathrm{NaCl}$ (agp) Merck. The initial sodium content of the olives was determined using the same technique as mentioned above.

The content of calcium was determined with a flame atomic absorption spectrometer (FAAS) Perkin Elmer (Uberlingen, Germany) model 2380, employing the same solutions used to quantify sodium, after the addition of $5 \%(\mathrm{v} / \mathrm{v})$ of a $10 \%$ $(\mathrm{w} / \mathrm{v})$ solution of strontium chloride in each sample to avoid interference from other elements. A calibration curve was prepared using a calcium standard solution made of $1.00 \mathrm{~g} / \mathrm{l}$ of $\mathrm{Ca}\left(\mathrm{NO}_{3}\right)_{2}$ a.g.p. Tetrahedron solution and $\mathrm{HNO}_{3}$ (agp) Merck $0,5 \mathrm{M}$. Five $\mathrm{ml}$ of this solution were diluted with deionized water in a $250 \mathrm{ml}$ volumetric flask to achieve a calcium concentration of $25 \mathrm{mg} / \mathrm{l}$. Thereafter, $0.25 ; 0.50 ; 0.75 ; 1.00 ; 1.50$ and 2.00 $\mathrm{ml}$ of this solution were placed in $25 \mathrm{ml}$ volumetric flasks into which $5 \%(\mathrm{v} / \mathrm{v})$ of a solution of $\mathrm{SrCl}_{2}$ (agp) Merck at 10\% (w/v) were added and brought to volume with deionized water. A blank with deionized water and $5 \% \mathrm{SrCl}_{2}$ at $10 \%$ was used for zero adjustment.

Reducing sugars were determined in the untreated olive flesh and in lye according to Miller's technique (Maldonado et al. 2008; Miller, 1959), employing a spectrophotometer Metrolab UVvisible model 325BD (Buenos Aires, Argentina).

Changes in firmness were measured with a penetrometer Wagner (Italy); model FT01, 500 gf $x$ $5 \mathrm{gf}$, using a $1 \mathrm{~mm}$ diameter plunger.

\subsection{Theoretical Considerations}

In order to calculate the effective diffusion coefficients of both solutes into the skin $\left(D_{S}\right)$ and the flesh $\left(D_{F}\right)$ during the debittering process, the diffusion model for a composite flat plate and constant diffusion coefficients used by Maldonado and Zuritz (2003) was adjusted to the experimental data.

The average volumetric concentration $<\mathrm{C}>$ of the analytical solution to the one-dimensional diffusion process with constant effective diffusion coefficients through a composite flat plate, consisting of a thick flesh $(L)$ and a thin skin $(\delta)$, expressed in dimensionless form, is given as (Maldonado and Zuritz, 2003):

$$
\langle C\rangle=2 \sum_{n=1}^{\infty} \frac{\sin ^{2}\left(\lambda_{n}\right)}{\lambda_{n}\left[\lambda_{n}+\sin \left(\lambda_{n}\right) \cos \left(\lambda_{n}\right)\right]} e^{-\lambda_{n}^{2} \theta}
$$

Where the $\lambda_{n}$ are the eigen values that satisfy the following eigen function:

$$
\lambda_{n} \tan \left(\lambda_{n}\right)=\frac{D_{S} / \delta}{D_{F} / L}
$$

In eq. (1) $<\mathrm{C}>$ and $\theta$ are respectively:

$$
\langle\mathrm{C}\rangle=\frac{\left\langle\mathrm{c}_{(\mathrm{t})}\right\rangle-\mathrm{c}_{\mathrm{s}}}{\mathrm{c}_{\mathrm{i}}-\mathrm{c}_{\mathrm{s}}} \text { and } \theta=\frac{\mathrm{D}_{\mathrm{F}}}{\mathrm{L}^{2}} \mathrm{t}
$$

The flesh diffusivities $\left(D_{F}\right)$ and eigen values $\lambda_{1}$ for each treatment were estimated using the least squares method, which minimizes the function:

$$
S=\sum_{i=1}^{N}\left(\langle c\rangle_{\exp }-\langle c\rangle_{\text {calc }}\right)^{2}
$$

Since the sum of squares of the residuals given as equation (3) is a non-linear function of the flesh effective diffusion coefficients $D_{F}$ and the eigen values $\lambda$, the iterative non-linear regression method implemented in the program Microsoft Excel Solver ${ }^{\circledR}$ was used. Next, the skin effective diffusion coefficients, $D_{S}$, were determined with equation (2).

\section{RESULTS}

At the beginning of the lye treatment, as the $\mathrm{NaOH}$ comes into contact with the skin surface, it takes some time before the lye removes the epicuticular wax and facilitates the diffusion of $\mathrm{NaOH}$ into the flesh. Table 1 shows the variation of the average $\mathrm{NaOH}$ concentration of the lye in both containers during the debittering process.

Table 1 shows that the concentration of $\mathrm{NaOH}$ decreased from $2.5 \%$ to a final value of $1.59 \%$ in 7.5 hours, which represents an almost $37 \%$ consumption of lye. The diffusion of the lye into

Table 1

Average lye concentration during debittering

\begin{tabular}{cc}
\hline $\begin{array}{c}\text { Treatment } \\
\text { time } \\
\text { (hours) }\end{array}$ & $\begin{array}{c}\text { Lye } \\
\text { concentration } \\
(\%)\end{array}$ \\
\hline 0.0 & 2.50 \\
2.5 & 2.07 \\
4.5 & 1.82 \\
6.5 & 1.64 \\
7.5 & 1.59 \\
\hline
\end{tabular}


the fruit increased the $\mathrm{pH}$ of the flesh from an initial value of 5 to a final value of 12 . This increase in $\mathrm{pH}$ is an indication of the excess lye that diffused into the flesh.

The lye is an electrolytic solution where the ions sodium and hydroxyl are completely dissociated. These dissociated species have different electric charge according to their dilution. They have different degrees of solvation (Whitten and Gailey, 1988). Consequently, their affinity and capacity of combination with the olives' matrix components (pectins, fatty acids, tannins, etc) are differential and selective. They also have different particle sizes (Whitten and Gailey, 1988). Therefore, due to their selective degree of combination, reactivity and particle size, it could be assumed that their diffusivity through the olive flesh would also be different. Probably, when the hydroxyl ion diffuses into the fruit cells, it reacts forming water with hydrogen protons coming from the carboxyl groups of the fatty acids and from the hydrolysis of oleuropein, pectins, etc, partially hydrating the olive flesh. Therefore, the hydroxyl ion could be considered the true reactive ion with the components of the flesh, which disappear as such by forming water. A diffusion analysis based on the hydroxyl ion should include the corresponding rate of the reaction term in the continuity equation (Fick's Second Law of diffusion). On the other hand, even though the sodium ion also combines with fatty acids, pectins, etc., it does not transform as a species. For that reason, it can be traced inside the flesh in terms of total sodium content in each spatial dimension, regardless of whether it is in a free or combined state. In this case, a diffusion analysis based on the sodium ion does not need to include the rate of the reaction term in the continuity equation (Maldonado and Zuritz, 2003).

Based on these considerations, the following general reaction that could occur between $\mathrm{NaOH}$ and the fatty acids of the cuticle and the flesh cells can be proposed:

$$
\mathrm{RCOOH}+\mathrm{NaOH} \leftrightarrow \mathrm{RCOONa}+\mathrm{H}_{2} \mathrm{O}
$$

Figure 1 shows the variation in $\mathrm{Na}^{+}$ion concentration within the flesh during the lye treatment. The distances represent the location of the center of each sample measured from the surface of the pit towards the skin.

The initial average concentration of $\mathrm{Na}$ in the fruit was $0.0045 \mathrm{meq} \mathrm{Na} / \mathrm{g}$ of olive flesh. The figure shows a progressive increase in concentration with time in all the sections. As expected, this increase is more pronounced in the outer layer. At the end of the debittering process the average concentration of $\mathrm{Na}$ in the olive was $0.305 \mathrm{meq} \mathrm{Na} / \mathrm{g}$ of olive flesh, with a minimum value of $0.200 \mathrm{meq} \mathrm{Na} / \mathrm{g}$ of olive flesh at the inner layer in contact with the pit and of $0.395 \mathrm{meq} \mathrm{Na} / \mathrm{g}$ of olive flesh in the outer layer in contact with the lye.

Initially, the pectins of the middle lamella in the olives would be in the form of coiled chains linked through calcium bridges (Jimenez et al., 1995). This arrangement is shown schematically in Figure 2. As indicated above, cell-cell adhesion is controlled by $\mathrm{Ca}^{+2}$ and its removal or displacement by $\mathrm{Na}^{+}$ions could reduce tissue firmness. For this reason, the content of Ca was also measured in both the pulp and the treatment liquid. The results are shown in the following figures. As mentioned before, the distances in the olive flesh represent the location

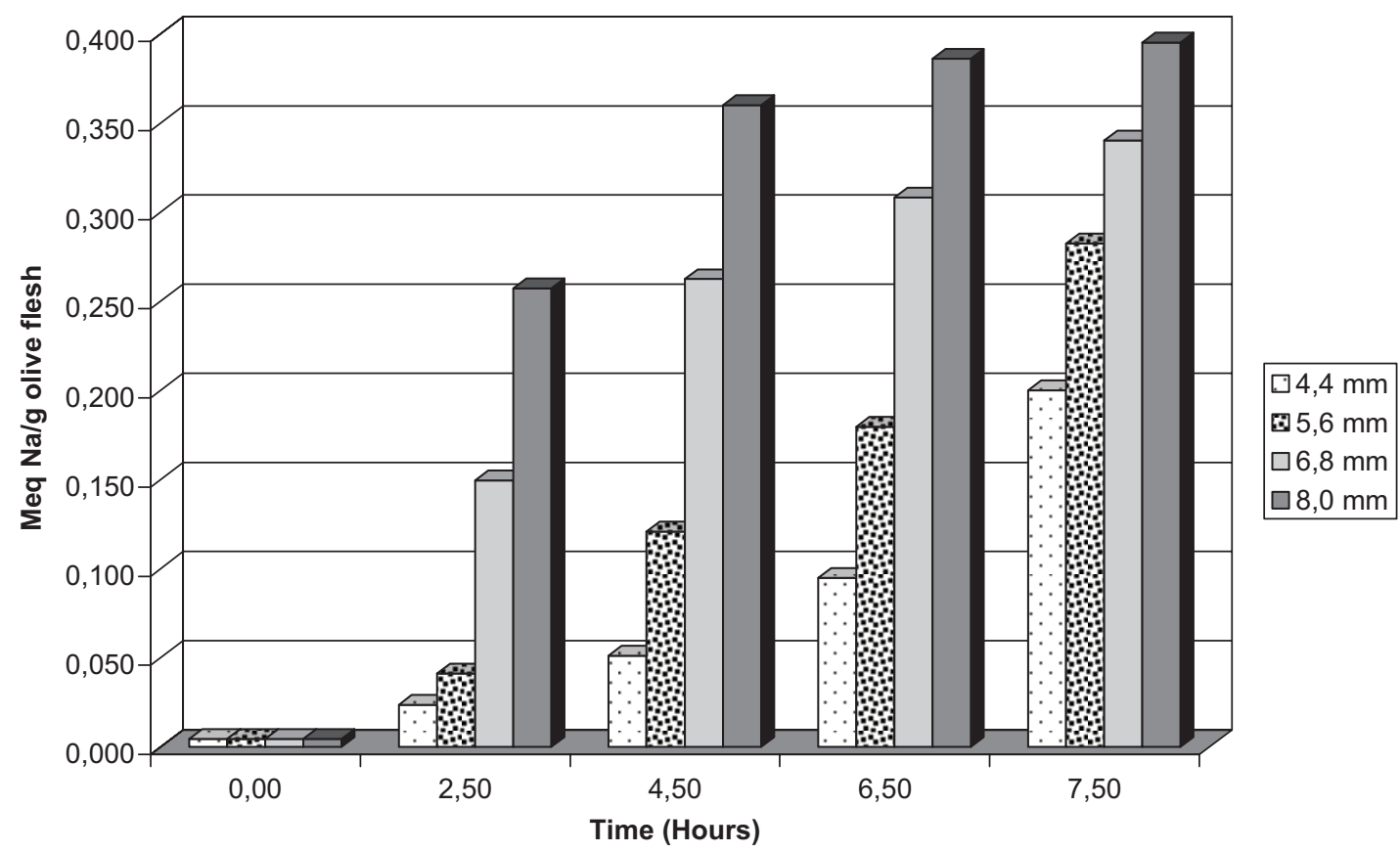

Figure 1

Concentration of sodium within the olive flesh during the debittering process. (Shown distances are from the pit outward). 
of the center of each sample measured from the surface of the pit towards the skin.

Figure 3 shows the $\mathrm{Ca}$ concentration in the olive flesh. It can be observed that at the beginning of the debittering process, the initial average concentration of Ca was $0.018 \mathrm{meq} \mathrm{Ca} / \mathrm{g}$ of olive flesh. Afterwards, it started to increase progressively due to the calcium concentration in the lye, following a pattern similar to that shown with $\mathrm{Na}$, but with a smaller slope. The final average concentration of $\mathrm{Ca}$ was $0.0233 \mathrm{meq}$ $\mathrm{Ca} / \mathrm{g}$ of olive flesh, with a minimum value of 0.0211 meq $\mathrm{Ca} / \mathrm{g}$ of olive flesh at the inner layer in contact with the pit and of 0.0252 meq $\mathrm{Ca} / \mathrm{g}$ of olive flesh in the outer layer in contact with the lye.

The concentration of calcium in the lye during the debittering time is shown in Figure 4. The initial concentration of calcium in the lye was equal to 29.12 meq $\mathrm{Ca} / \mathrm{l}$. This was due to the presence of native salts such as $\mathrm{CaCO}_{3}, \mathrm{Ca}\left(\mathrm{CO}_{3} \mathrm{H}\right)_{2}$ and $\mathrm{CaSO}_{4}$ in the water used to prepare the lye, typical water of the region of Mendoza (dates not shown). Thereafter, the calcium concentration continuously decreased to a final value

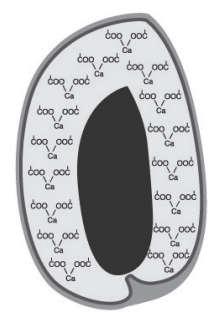

Figure 2

A simple representation of the calcium bridges of pectins of the middle lamella. Light grey represents the waxy layer. Dark grey represents the epidermis. of $24.40 \mathrm{meq} \mathrm{Ca/l}$. This decrease in calcium in the treatment liquid corresponds to the increase of this ion in the olive flesh.

The diffusion of $\mathrm{Ca}$ into the flesh was two orders of magnitude less than the diffusion of $\mathrm{Na}$. For instance, while the average concentration of $\mathrm{Ca}$ increased with time from 0.018 to only 0.0233 meq $\mathrm{Ca} / \mathrm{g}$ of olive flesh, the concentration of $\mathrm{Na}$ increased from 0.0045 to $0.305 \mathrm{meq} \mathrm{Na} / \mathrm{g}$ of olive flesh. This difference in ion uptake by the olive flesh was due to the concentration gradient of each ion between the treatment liquid and the olives. The debittering solution had an initial concentration of sodium of $625 \mathrm{meq} \mathrm{Na} / \mathrm{l}(\mathrm{NaOH}$ at $2.5 \%)$ and of calcium equal to 29.12 meq $\mathrm{Ca} / \mathrm{l}$. Expressing these concentrations in terms of grams of olive flesh, the gradients would be respectively $0.6930 \mathrm{meq} \mathrm{Na} / \mathrm{g}$ in the liquid versus $0.0045 \mathrm{meq} \mathrm{Na} / \mathrm{g}$ in the olive flesh, while for calcium it would be $0.0323 \mathrm{meq}$ $\mathrm{Ca} / \mathrm{g}$ in the solution versus $0.0181 \mathrm{meq} \mathrm{Ca} / \mathrm{g}$ in the olive flesh. In this context, the concentration gradient of $\mathrm{Na}$ was two times greater than the concentration gradient of CThe diffusion would be facilitated by the small ionic radius of these two ions, which are $0.95 \mathrm{~A}^{\circ}$ for $\mathrm{Na}^{+}$and $0.99 \mathrm{~A}^{\circ}$ for $\mathrm{Ca}^{2+}$ (Whitten and Gailey,1988). Nevertheless, the $\mathrm{Ca}^{2+}$ ion in the water can be in two different forms. On one hand, it is forming $\mathrm{CaCO}_{3}$ in a colloidal state with very low solubility in water (Vogel, 1960), therefore almost not dissociated, in which case it would have to diffuse as a salt with a much larger molecular radius. And on the other hand, $\mathrm{Ca}\left(\mathrm{CO}_{3} \mathrm{H}\right)_{2}$ completely dissociated as $\mathrm{Ca}^{2+}$ (Vogel, 1960).

Another factor to be considered is the electro negativity of the ions. At 0.93 for $\mathrm{Na}$ and 1.0 for $\mathrm{Ca}$

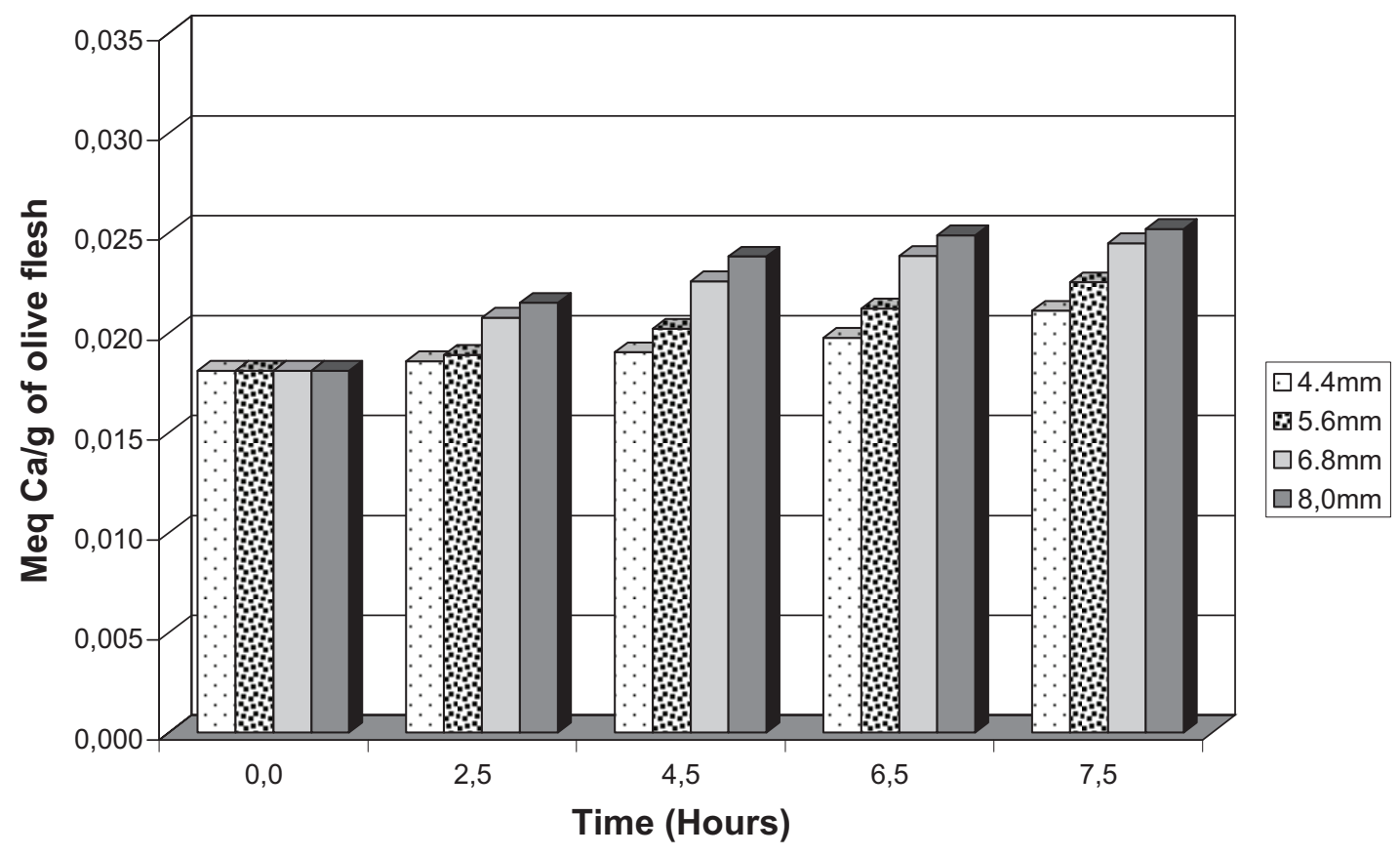

Figure 3

Concentration of calcium within the olive flesh during the debittering process. (Shown distances are from the pit outward). 
(Pauling, 1932), the calcium ion would have more capacity to establish a stable linkage with $\mathrm{COO}^{-}$ groups from pectins than sodium ions. But the sodium ions are in larger quantity. Thus, each ion would have a different diffusion through the olive flesh and probably interact in different ways with the channel diffusion walls.

It should also be considered that the $\mathrm{Ca}^{+}$ion has not only more electro negativity than the $\mathrm{Na}^{+}$ion, but also a larger ionic radius that would make its diffusion into the flesh more difficult.

The effective diffusion coefficients of both ions, determined form the experimental data are shown in Table 2. For both ions, the values of the effective diffusion coefficients in the skin $\left(D_{S}\right)$ are two times smaller than the values in the flesh $\left(D_{F}\right)$. Furthermore, the effective diffusion coefficients for $\mathrm{Na}$ are slightly larger than the values for $\mathrm{Ca}$, which would be in agreement with what was indicated above regarding the ionic radius of the ions and the larger quantity of sodium. These results of effective diffusion coefficients for $\mathrm{Na}$ are in agreement with those obtained by Maldonado and Zuritz (2003) in their laboratory scale experiments with constant lye concentrations.

As mentioned before, the initial calcium content in the olives would be responsible for the original firmness of the flesh. Figure 5 shows the evolution of firmness during the debittering process. Each value is the average of 20 readings. The firmness decreased from $375 \mathrm{gf}$ to $235 \mathrm{gf}$ in 7 and $1 / 2$ hours of processing. The decrease in firmness of the olive flesh takes place in as much as the $\mathrm{Na}^{+}$diffusing into the flesh reacts with the pectins and dislodges the ion $\mathrm{Ca}^{2+}$ (Jiménez et al., 1995, 1997). Although the olives experienced a significant softening, the concentration of calcium increased during the debittering process due to the higher $\mathrm{Ca}^{2+}$ concentration in the lye than in the olive flesh. Nevertheless, the $\mathrm{Ca}^{2+}$ dislodgment takes place due to the ionic competition between both ions as a result of the much higher $\mathrm{Na}^{+}$than $\mathrm{Ca}^{2+}$ concentration established within the olive flesh during the debittering process.

When the olives are initially placed in the lye, the ions in the aqueous solution encounter the cuticle, a non polar lipophylic barrier, made of wax, cutine, cellulose, pectins, hydrocarbons, cratecolic acid, oleanolic acid, triterpenic alcohols, etc. (Vázquez Roncero et al., 1967), that has to be initially dissolved by the $\mathrm{NaOH}$, before the diffusion process could take place in full strength. Once this step is accomplished, the diffusion flow rate would be controlled by the structure of the skin and the flesh as well as by the concentration of ions in the lye (Maldonado et al., 2003).

Table 2

Effective diffusion coefficients of $\mathrm{Na}$ and $\mathrm{Ca}$ in the olive flesh $\left(D_{F}\right)$ and skin $\left(D_{S}\right)$

\begin{tabular}{cccc}
\hline Solute & $\begin{array}{c}\mathrm{DF} \\
\left(\mathrm{m}^{2} / \mathbf{s}\right)\end{array}$ & $\begin{array}{c}\text { DS } \\
\left(\mathbf{m}^{2} / \mathbf{s}\right)\end{array}$ & $\begin{array}{c}\text { Regression } \\
\left(\mathbf{r}^{2}\right)\end{array}$ \\
\hline Sodium $(\mathrm{Na})$ & $6.25 \times 10^{-10}$ & $7.58 \times 10^{-12}$ & 0.956 \\
Calcium $(\mathrm{Ca})$ & $5.16 \times 10^{-10}$ & $6.26 \times 10^{-12}$ & 0.994 \\
\hline
\end{tabular}

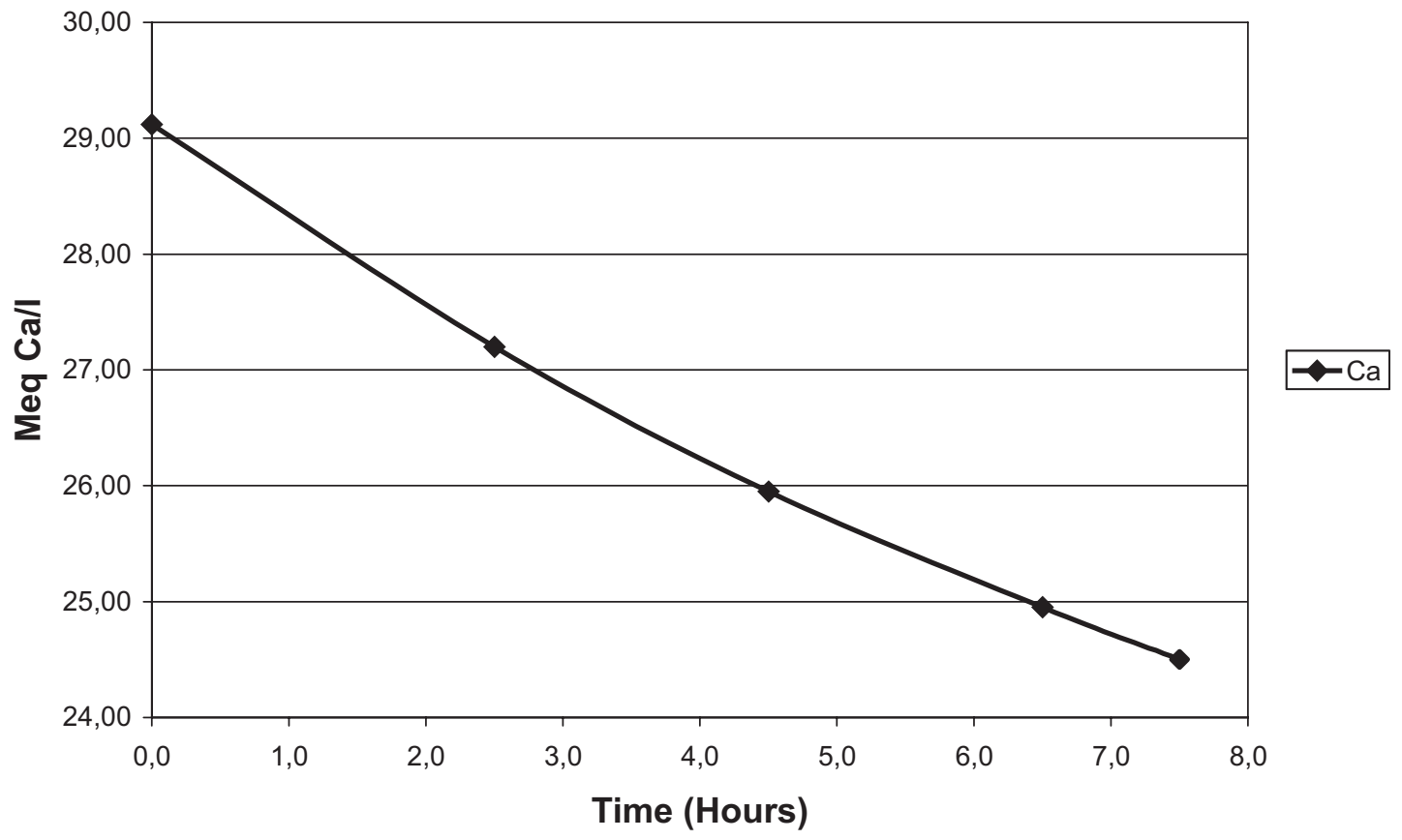

Figure 4

Concentration of calcium in the debittering lye. 


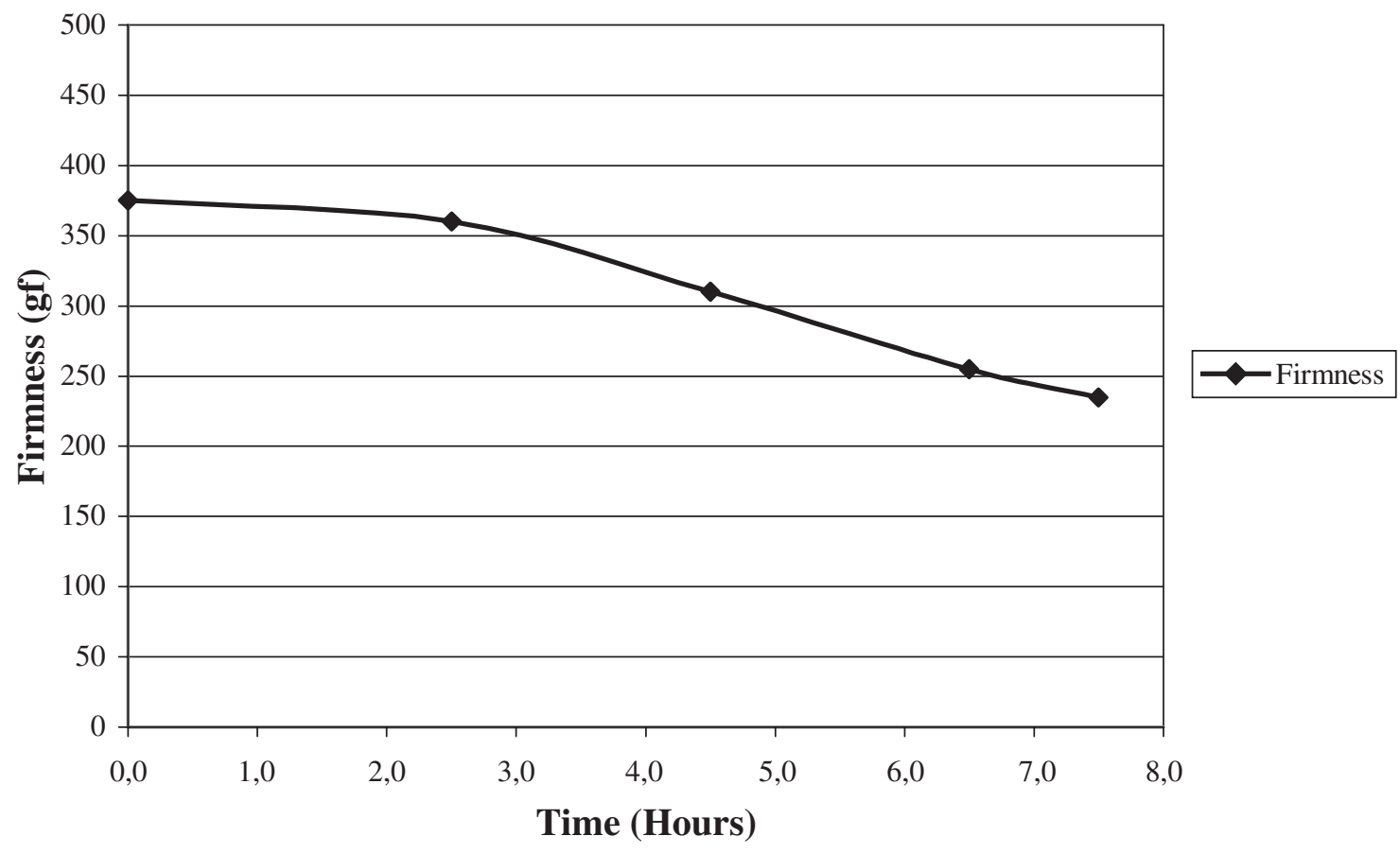

Figure 5

Evolution of firmness of olives during debittering.

As shown in Figure 6, the following simplified dynamic model of ions and charge distribution could be proposed, when the olives are initially placed in the $\mathrm{NaOH}$ solution. The initial $\mathrm{pH}$ of the olive flesh was 5 , which gives an acidic medium resulting from the high concentration of fatty acids and other acids (citric, malic and oxalic acids; Fernández Díez and González Pellissó, 1956) present in the fruit. However, the positive charge of the flesh would be initially isolated from the outside by the cuticle. After the hydroxyl ions (with negative charge) have dissolved the cuticle "exposing" the flesh positive charge, the negative ions hydroxyl on the surface of the olives will react with the pectins in the cellular wall of the epidermis, forming water with the hydrogen protons of $\mathrm{COOH}$ groups and simultaneously opening the way to the diffusion of $\mathrm{Na}^{+}$ ions towards the inside of the flesh and cells, where they will combine with $\mathrm{COO}^{-}$groups of the pectins, fatty acids and other organic acids, probably establishing the charge distribution shown in Figure 7. The hydroxyl ion would be the first to react, dissolving the cuticle (shown in light grey in the Figures). Thereafter, the $\mathrm{Na}^{+}$ion enters into the fruit and reacts with the $\mathrm{COO}^{-}$groups, by competition and displacing the $\mathrm{Ca}^{2+}$ ions that link contiguous pectic chains, causing their uncoiling. This generates a more linear and lax pectic structure and probably provokes the softening of the fruit. Although the percentage of displacement of $\mathrm{Ca}^{2+}$ ions is small (Jiménez et al., 1997), but apparently, it is sufficient to generate this softening, which in the present case translated to a loss of firmness from $375 \mathrm{gf}$ to $235 \mathrm{gf}$. This loss of firmness associated to a disruption of the structure of the tissue would facilitate the diffusion of sugars, and other constituents such as products of the break up of the oleuropein, phenolic compounds, etc. out of the fruit.
As the hydroxyl ion reacts with the components of the cell wall, forming water with the hydrogen protons, decreasing the positive charge, there will be an increase in negative charges in the cellular structure and consequently an increase in $\mathrm{pH}$ to neutrality, and most of the $\mathrm{COO}^{-}$groups would remain ionized. As was indicated previously, the excess of hydroxyl ions further increases the $\mathrm{pH}$ to a value of 12 . This high $\mathrm{pH}$ will be reverted to an acidic level $(\mathrm{pH}=4.5)$ during the fermentation process in a subsequent step.

The change in electronic density in the flesh allows the combination of $\mathrm{Na}^{+}$ions to $\mathrm{COO}^{-}$groups, generating not only pectins with a loose structure, but also the saponification of fatty acids and the break up of the oleuropein into 3,4-hydroxyfenilethyl alcohol or hydroxytyrosol and eleanolic acid.

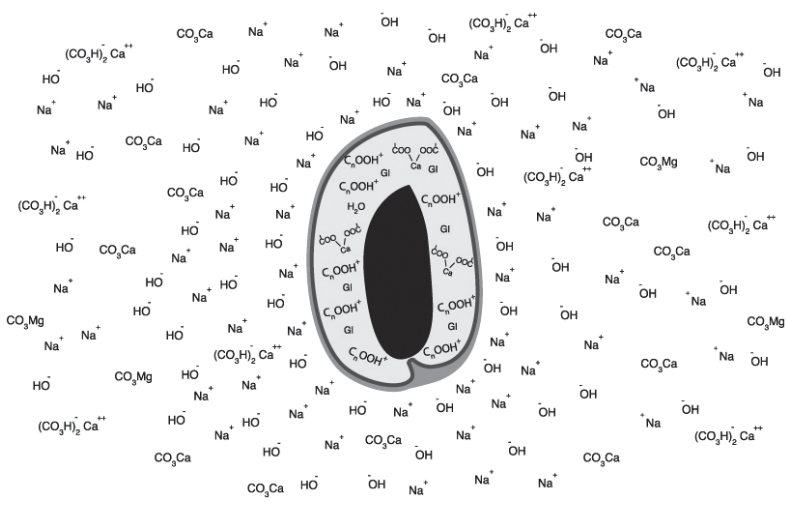

Figure 6

A simplified model of ions and charge distribution when the olives are initially placed in the

$\mathrm{NaOH}$ solution (Gl: glucose, $\mathrm{CnCOOH}^{+}$: fatty acids). 
As the surface is surrounded by negative charges, the following model of charge distribution could be proposed, as shown in Figure 8.

The loss of reducing sugars during the debittering process (Fig. 9) represented an average value of $25.9 \%$ of the initial content in the olives. A fraction of the remaining $74.1 \%$ would be lost during the subsequent rinsing steps. For this reason, the debittering and the rinsing steps should be carefully controlled in order to avoid an excessive loss of sugars that could hinder the lactic fermentation process, as they are the source of carbon used by the lactic bacteria. This loss of sugars is mainly due to the structural disruption of the flesh tissue and their solubility in water.

It has been said that the alkali treatment modifies the polysaccharides of the cell wall, breaks up the

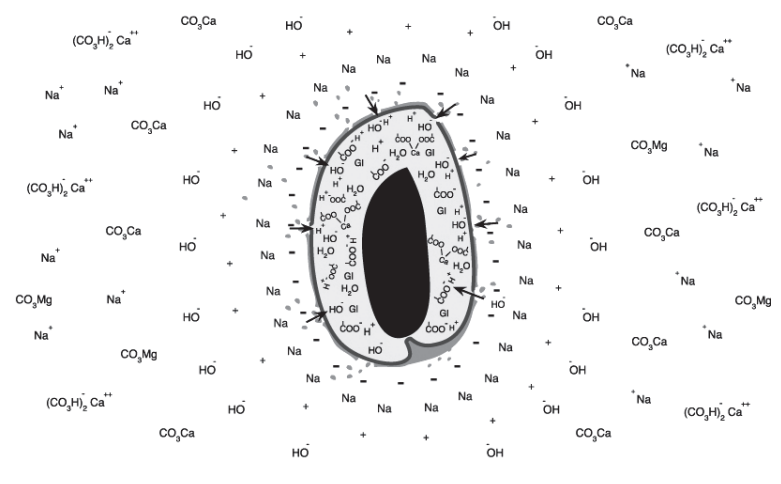

Figure 7

Position of negative and positive ions around the surface of the olives and formation of a double layer during the removal of the wax layer. The negative charges surrounding the olives represent the hydroxyl ions. Gl represents glucose. Arrows indicate entry of $\mathrm{OH}^{-}$ions. weak links and probably the reducing ends are slowly degraded (Gil Martinez, 1995). In contrast with this hypothesis, we propose that what could really occur is not a degradation of the reducing ends, but rather an increase in the number of reducing molecules due to the degradation of the hydrocarbon chain in the alkali medium. In this medium, a lot of molecules of shorter length, with reducing power, can be formed from the glucose molecules. Therefore, the number of molecules with reducing power would be greater (Future studies will be undertaken in order to confirm this hypothesis).

\section{CONCLUSIONS}

The change in concentration of sodium and calcium ions during the debittering process was

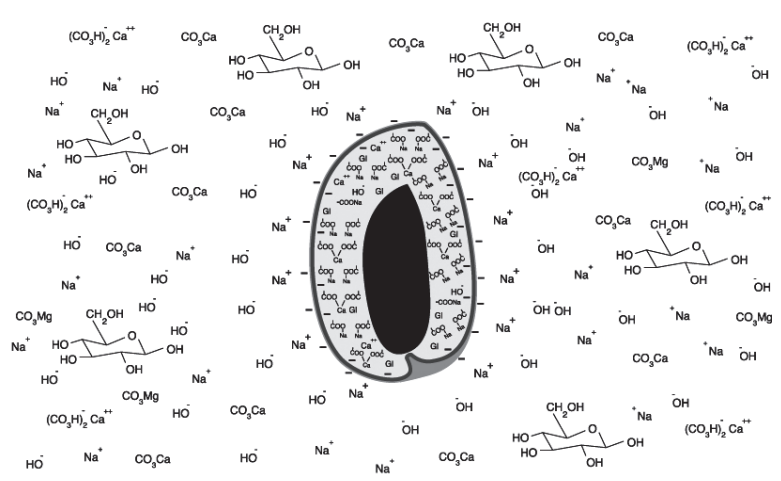

Figure 8

Simplified model of the unwinding of the pectinic structure and exit of reducing sugars into the lye during the debittering process. Gl represents glucose still remaining in the olives.

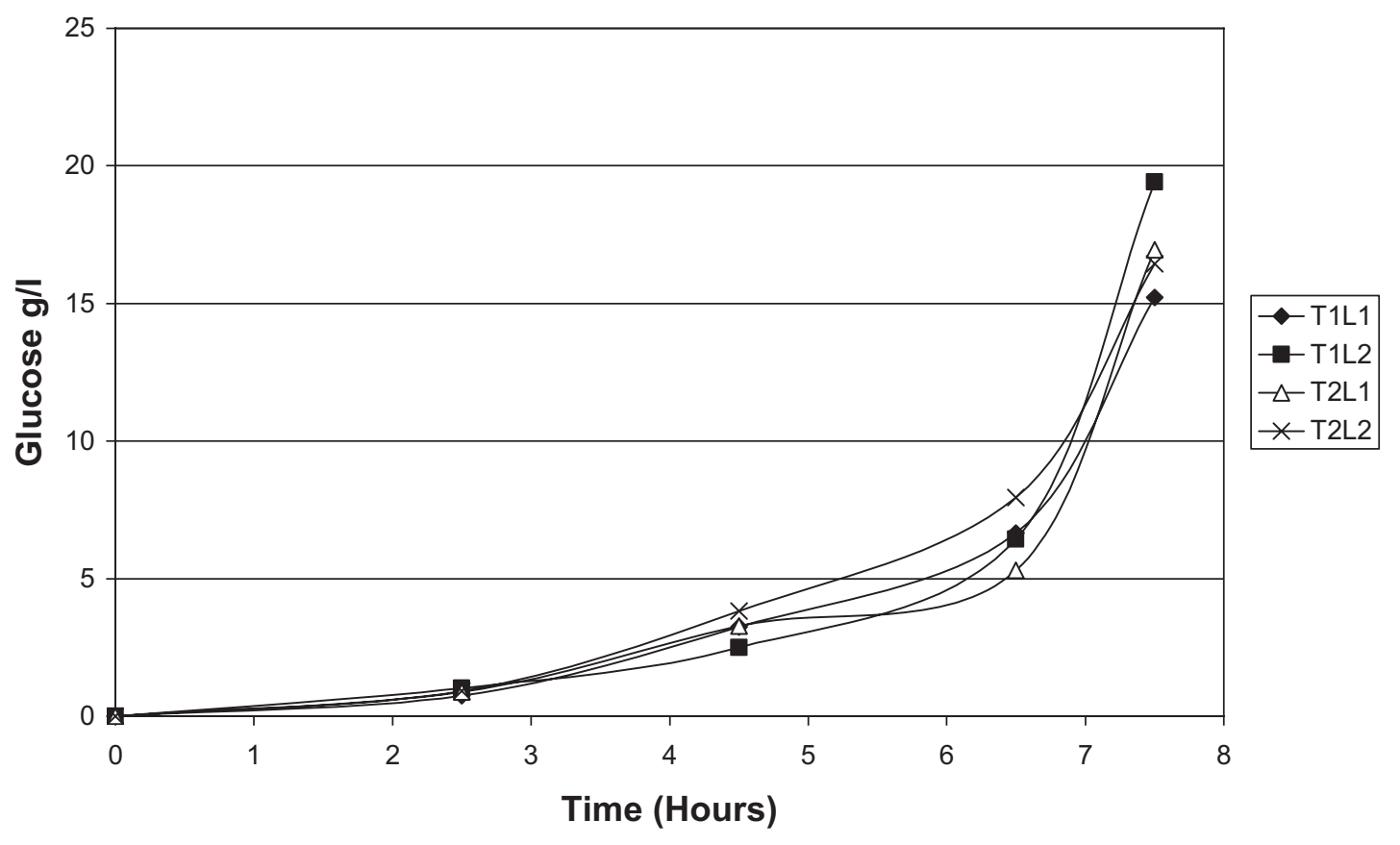

Figure 9

Loss of reducing sugars into the lye during debittering. $\mathrm{T}$ : represent tank and $\mathrm{L}$ : depth level within each tank. 
quantified in the olive flesh and in the lye. Both concentrations decreased in the lye and increased in the olive flesh. The average concentration of $\mathrm{Na}$ increased from 0.0045 to $0.395 \mathrm{meq} \mathrm{Na/g}$ of olive flesh and the concentration of $\mathrm{Ca}$ increased from 0.018 to $0.0233 \mathrm{meq} \mathrm{Ca} / \mathrm{g}$ of olive flesh. The firmness of the olives decreased almost linearly from $375 \mathrm{gf}$ to $235 \mathrm{gf}$ during the alkali treatment. They also suffered a $25.9 \%$ loss in reducing sugars. The values of the effective diffusion coefficients in the skin $\left(D_{S}\right)$ were two times smaller than the values in the flesh $\left(D_{F}\right)$, at $D_{S}$ in the order of $10^{-12}$ and $D_{F}$ in the order of $10^{-10}$, respectively.

A hypothetical simplified description of the dynamic of ionic charge changes and unwinding of the pectinic structure during the debittering process of green olives has been proposed.

\section{NOMENCLATURE}

\begin{tabular}{|c|c|}
\hline$<\mathrm{C}>$ & $\begin{array}{l}\text { Dimensionless volume averaged } \\
\text { concentration of solute. }\end{array}$ \\
\hline $\mathrm{C}_{\mathrm{i}}$ & $\begin{array}{l}\text { Initial concentration of solute (meq/g olive } \\
\text { flesh) }\end{array}$ \\
\hline $\mathrm{c}_{\mathrm{S}}$ & $\begin{array}{l}\text { Solute average concentration at the outer } \\
\text { skin surface (meq/g lye) }\end{array}$ \\
\hline$\left.<\mathrm{C}_{(\mathrm{t})}\right\rangle$ & $\begin{array}{l}\text { Solute concentration within the olive flesh } \\
\text { at different time intervals (meq/g olive } \\
\text { flesh) }\end{array}$ \\
\hline$D_{F}$ & Flesh effective diffusion coefficient $\left(\mathrm{m}^{2} / \mathrm{s}\right)$ \\
\hline$D_{S}$ & Skin effective diffusion coefficient $\left(\mathrm{m}^{2} / \mathrm{s}\right)$ \\
\hline $\mathrm{L}^{\circ}$ & Thickness of the olive flesh (m) \\
\hline $\mathrm{t}$ & Time (s) \\
\hline$\delta$ & Skin thickness (m) \\
\hline$\lambda_{n}$ & Eigen values \\
\hline$\theta$ & Dimensionless time \\
\hline
\end{tabular}

\section{ACKNOWLEDGEMENT}

CONICET, Argentina; INTA Argentina, Establecimiento Olivícola Atilio Avena e Hijos S.A., Mendoza, Argentina.

\section{REFERENCES}

Barranco D, Fernández Escobar D, Ballo L. 1997. El cultivo del olivo. Coedición Junta de Andalucía. Consejería de Agricultura y Pesca. Ediciones Mundi Prensa.

Coimbra MA, Waldron KW, Delgadillo I and Selvendran RR. 1996. Effect of processing on cell wall polysaccharides of green table olives. J. Agric. Food Chem. 44, 23942401.

Drusas A, Vagenas GK, Saravacos GD. 1988. Diffusion of sodium chloride in green olives. J. Food Eng. 7, 211- 222.

Fernández Díez MJ and González Pellissó F. 1956. Cambios de la composición de la aceituna durante su desarrollo, Vol. II. La acidez y pH del jugo. Determinación de ácidos oxálico, cítrico y málico. Grasas y Aceites, 7, 185-189.

Fernández MH, Uceda Ojeda M, García-Ortiz Rodríguez A, Morales Bernardino J, Friaz Ruiz L y Fernández García A. 1991. Apuntes: Elaboración de aceite de oliva de calidad. Junta de Andalucía Consejería de Agricultura y Pesca. 5/91:36-38.

Floros JD, Wetzstein HY and Chinnan MS. 1987. Chemical $(\mathrm{NaOH})$ peeling as viewed by scanning electron microscopy: pimiento peppers as a case study. J. Food Sci. 52, 1312-1320.

Gil Martinez F. 1995. Elementos de Fisiología Vegetal. Relaciones Hídricas. Nutrición Mineral. Transporte. Metabolismo. Ediciones Mundi-Prensa. Madrid. Barcelona. México.

Jiménez A, Guillén R, Sánchez C, Fernández-Bolaños J and Heredia A. 1995. Changes in texture and cell wall polysaccharides of olive fruit during "Spanish Green Olive" processing. J. Agric. Food Chem. 43, 22402246.

Jiménez A, Guillén R, Sánchez C, Fernández-Bolaños $J$ and Heredia A. 1996. Molecular weight and ionic characteristics of olive cell wall polysaccharides during processing. J. Agric. Food Chem. 44, 913-918.

Jiménez A, Guillén R, Sánchez C, Fernández-Bolaños J and Heredia A. 1997. Factors affecting the "Spanish Green Olive" processing: their influence on final texture and industrial losses. J. Agric. Food Chem. 45, 4065-4070.

Jiménez A, Heredia A, Guillén R and Fernández-Bolaños J. 1997. Correlation between soaking conditions, cation content of cell wall, and olive firmness during "Spanish green olive" processing. J. Agric. Food Chem. 45, 1653-1658.

Jiménez A, Sánchez C, Guillén R, Fernández-Bolaños $J$ and Heredia A. 1998. Solubilization of cell wall polysaccharides from olive fruits into treatment liquids during "Spanish Green Olive" processing. J. Agric. Food Chem. 46, 4376-4381.

Lombardi A and Zaritzky N. 1997. Mathematical modeling of the simultaneous diffusion of citric acid and ascorbic acid in vegetable tissue. Investigación Aplicada Latinoamericana. 27 (1-2): 25-38.

Maldonado MB and Zuritz CA. 2004. Difusión de sodio durante el tratamiento alcalino de aceitunas variedad Aloreña. Grasas y Aceites 55, 409-414.

Maldonado MB, Zuritz CA and Assof M. 2008(a). Diffusion of glucose and sodium chloride in green olives during curing as affected by lye treatment. $J$. Food Eng. 84, 224-230

Maldonado MB, Zuritz CA and Miras N. 2008(b). Influence of brine concentration on sugar and sodium chloride diffusion during the processing of the green olive variety Arauco. Grasas y Aceites. 59, 265-271.

Maldonado MB and Zuritz CA. 2004. Determination of Variable Diffusion of Sodium During the Debittering of Green Olives. J. Food Proccess Eng. 27, 345-358.

Maldonado MB and Zuritz CA. 2003. A Model for Diffusion of Sodium in Green Olives at Different Temperatures and Lye Concentrations. J. Food Process Eng. 26, 336-359

Maldonado MB, Zuritz CA, Gascón AD y Rey E. 2003. Difusión de Sodio en Aceitunas Verdes Durante el Tratamiento Alcalino: I Efecto de Concentración de la Lejía. Grasas y Aceites 54, 358-364.

Miller GL. 1959. Use of dinitrosalicylic acid reagent for determination of reducing sugar. Anal. Chem. 31, 426-428.

Pauling, L. 1932. The Nature of the Chemical Bond. IV. The Energy of Single Bonds and the Relative Electronegativity of Atoms. Journal Am. Chem. Soc. 54, 3570-3582

Rodriguez de la Borbolla y Alcalá JM, Rejano NL. 1979. Sobre la preparación de aceitunas de estilo sevillano. La fermentación I. Grasas y Aceites 30, 175-185. 
Sciancalepore V. 1984. Temperature of lye treatment during preparation of sevillan styles olives. Industrie Alimentari. 23, 941-944.

Vázquez Roncero A, Maestro Durán R y Ruiz Caravajal J. 1967. Composición de la cutícula de las aceitunas. Grasas y Aceites 5, 253-256.

Vogel A. 1960. Química analítica cuantitativa volumen I Volumetría y gravimetría. Editorial Kapeluz. Buenos Aires.

Whitten KH y Gailey K L. 1988. Química General. Interamericana. México. D. F.
Zuritz CA, Maldonado MB y Gascón AD. 2003. Difusión de Sodio en Aceitunas Verdes Durante el Tratamiento Alcalino: II Efecto de la Temperatura de la Lejía. Grasas y Aceites 54, 365-370.

Zuritz CA and Maldonado MB. 2004. A Simple Method to Determine Diffusion of Sodium in Epidermis of Green Olives. J. Food Proccess Eng. 27, 328-344.

Recibido: $26 / 2 / 10$ Aceptado: 19/4/10 